\title{
Relative gains and the Common Agricultural Policy: the French government's decision to reject the Blair House Agreement and block the completion of the Uruguay Round in 1993.
}

\author{
Daniel Norrie ${ }^{1}$ \\ Monash University undergraduate student \\ dan_norrie@live.com.au
}

\begin{abstract}
The French government's rejection of the Blair House Agreement in 1993 enabled France to resist agricultural reform and achieve relative gains over other European Union States. The existence of the Common Agricultural Policy (CAP) allows France to extract the economic surplus of European Union (EU) members through taxes and subsidies, which artificially improve the competitiveness of French agriculture. France took advantage of the EU principle of consensus by adopting a strategy of non-compliance to agricultural negotiations, positioning it to directly influence EU Commission policy. This allowed France to benefit from EU bargaining power in the Uruguay Round, and ensure greater concessions from States driving agricultural reform. The reinstatement of veto power in the EU Community has made future agricultural reform more difficult, allowing France to continue to realise welfare gains at the expense of other EU members. The paper adopts a literature review to analyse French national interest and the costs and benefits of foreign policy strategies.
\end{abstract}

Key words: Blair House Agreement, Common Agricultural Policy, European Union, France, realism, Uruguay Round

In this paper it will be contended that France chose to reject and pressure for the renegotiation of the Blair House Agreement in 1993 because it threatened the Common Agricultural Policy (CAP) and French interests in protecting its agricultural industry. Furthermore it will also be argued that France adopted a strategy of noncompliance and coalition building within the European Union (EU) to safeguard its competitiveness and dominance of both EU and worldwide food markets.

In an effort to progress the Uruguay Round, the European Commission and the US concluded the Blair House Agreement in November 1992, which was designed to reduce agricultural protectionism. ${ }^{2}$ However France regarded this agreement as threatening its agricultural industry, which is protected and subsidised in order to maintain its competitiveness both within the EU and externally. ${ }^{3}$ As a result, France sought to reopen agricultural negotiations and reduce the degree of liberalization required by the Accord.4 France adopted dual strategies of maintaining a GATT veto as long as possible and engaging in consensus building within the EU to gain support

\footnotetext{
${ }^{1}$ In 2011 Daniel Norrie won the Undergraduate Essay Competition held by the Contemporary European Studies Association of Australia and sponsored by the European Union. Norrie is a Monash University graduate of the Bachelor of Arts (Dean's Scholars Program) degree. He is currently studying a Bachelor of Economics (Honours) degree at Monash University, with research interests in international trade and public finance.

${ }^{2}$ R. Lawrence et al. 'Imperfect Practice and the US-EU Trading Relationship',' in R. Lawrence, Crimes and Punishments? Retaliation Under the WTO, Washington DC, Institute for International Economics, 2003, pp. 6177.

3 S. Meunier, 'What Single Voice? European Institutions and EU-U.S. Trade Negotiations', International Organization, Vol. 54. No. 1, 2000, pp. 103-35.

4 R. Lawrence et al., op. cit.
} 
for its position. 5 This paper will show that the French delegation was able to take advantage of EU institutional rules to achieve its immediate aim of ensuring a review of the Accord, and secondly decreasing the degree of liberalization demanded.

During 1993, the French government sought to maintain it had no choice but to reject proposed reductions in the CAP because of their effect on domestic producer groups and citizens. French policy makers presented the view that the Blair House Agreement unnecessarily went further than the MacSharry CAP Reforms, ${ }^{6}$ and even that these two reforms were incompatible.7 Furthermore, the French government highlighted that violent protests and results from recent national elections meant that they had no manoeuvrability on the issue as the welfare and livelihood of its people were at stake. ${ }^{8}$ As a result other EU States recognised the credibility of a French veto under the Luxembourg Compromise, ${ }^{9}$ allowing the French to prevent further progress on CAP reform and the Uruguay Round.10

Secondly, France sought to influence the European Community through arguing that the Blair House Agreement undermined the fundamental principles of the Common Agricultural Policy and France's role as both a domestic and international agricultural producer. ${ }^{11}$ Firstly, it emphasized that provisions on market access would reduce France's competitiveness within the EU and thus derail the notion of Community preference. ${ }^{12}$ In addition, the French government articulated its goal to remain as an exporter of agricultural goods and stated that further dismantling of the CAP would undermine the ability of French agriculture to compete with world prices. As a result, French EU representatives emphasized that this was a direct threat to rural development and the CAP principal to maintain a reasonable standard of living for farmers. ${ }^{13}$ Furthermore, France sought to build up consensus support and argued that its role as an exporter contributed to outward EU influence. ${ }^{14}$ In fact, Agriculture Minister Louis Mermaz stated that correct CAP reform could improve the EC's leverage on international issues and enable the EU to use the CAP as a bargaining tool. 15

Finally, French EU representatives maintained that the European Commission had no mandate for the negotiating outcome that resulted from the Blair House Accord, and sought to reinstate French dominance over negotiations. ${ }^{16}$ France disagreed that the General Affairs Council had the authority to allow the Commission to bargain with third countries as they saw fit and to conclude an agreement. ${ }^{17}$ Furthermore,

\footnotetext{
5 S. Meunier, op. cit.

${ }^{6}$ MacSharry reduced the internal cereal price guarantee by 29 per cent over three years, and forced EU farmers to leave 15 per cent of their arable land idle, to guard against overproduction.

7 S. Meunier, op. cit.

8 Ibid.

9 The Luxembourg Compromise allows any state in the EU to veto a decision made by majority voting in the European Community if it threatens its vital national interests.

${ }^{10} \mathrm{~S}$. Meunier, op. cit.

${ }^{11}$ R. Lawrence et al., op. cit.

${ }^{12} \mathrm{~S}$. Meunier, op. cit.

Community preference is a principal of the CAP, where common import levies and export subsidies ensure those agricultural goods produced in the EC are favoured over those that come from outside the EC.

13 R. Lawrence et al., op. cit.

${ }^{14}$ S. Meunier, op. cit.

15 G. Alons, 'Predicting a State's Foreign Policy: State preference between Domestic and International Constraints,' Foreign Policy Analysis, Vol. 3, No.3, 2007. pp. 211-232.

${ }^{16} \mathrm{~S}$. Meunier, op. cit.

17 Ibid.
} 
France argued that the bilateral agreement concluded between the US and the EU had no legal value, and that there was no formal agreement. ${ }^{18}$ As a result, France sought to limit the autonomy of Commission negotiators Sutherland and MacSharry, so that it could reinforce the importance of unanimity and rally other Community partners to its defensive position on agriculture. ${ }^{19}$ Finally, it called for changes in EC internal procedures to ensure national governments had control over the Commission, so any state with divergent interests such as itself could not just be presented with a reduction of sovereignty through a "fait accompli."20

In evaluating the Blair House Accord, French policy makers perceived that it would hasten Common Agricultural Policy (CAP) reform and this as being deeply threatening and disadvantageous to strategic interests. ${ }^{21}$ Policy makers considered the Agreement in relative gains, a realist conception of foreign policy where States seek to maximise power gains relative to others. ${ }^{22}$ Firstly, it was interpreted that the Accord and provisions such as minimum market access were not permissible as they would lower the competitiveness of the French agricultural industry domestically. ${ }^{23}$ The French understood that this would reduce the ability of farmers to sell their goods, and undermine the CAP principal of Community preference, as it would hurt France's share of the internal EU food market.

Secondly, it was perceived that the Accord could not be allowed to detract from French agricultural competiveness and its role and influence as a food exporter. In fact, France was opposed to limiting the volume of agricultural exports, and instead preferred to limit subsidies, as this would enable France to indirectly compensate farmers for this loss of income and continue to maintain artificially low prices for its produce on world markets. ${ }^{24}$ The advocates of dependency theory argue that the importance of food security and food provision means that this can result in disproportionate gains in influence. ${ }^{25} \mathrm{~A}$ reduction in exports would impact the degree of interlinkage the French economy has with other States, and thus threaten French power. Ultimately, France was preoccupied with relative gains in power and influence, which occurred through the extraction of the economic surplus from other states in the EU.

Similarly, in contrast to its official pronouncements, the French Government had deeper strategic reasons for rejecting the Blair House Accord, namely that the continuance of the CAP allows it to realize strategic economic gains at the expense of other EU members. France is the greatest beneficiary of market distorting tariffs and subsidies for agriculture, ${ }^{26}$ which fund inefficient French production and artificially improve French GDP, at the expense of broader EU welfare. Thus, according to the

\footnotetext{
${ }^{18}$ L. Lueschen, 'French Agriculture: Trends and Policies,' Agribusiness, Vol. 11, No. 5, 1995, pp. 447-462.

19 Ibid.

${ }^{20} \mathrm{~S}$. Meunier, op. cit.

${ }^{21}$ Ibid.

${ }^{22}$ J. Ravenhill, 'Regional trade agreements' in Global political economy, 3rd ed., Oxford, Oxford University Press, 2010, p. 173-212.

${ }^{23}$ Europa Press Release. 1993. 1685TH Council Meeting Notes. General Affairs / Agriculture Brussels, 20/21 September.

$<$ http://europa.eu/rapid/pressReleasesAction.do?reference=PRES/93/145\&format=HTML\&aged=1\&language $=\mathrm{E}$ N\&guiLanguage $=$ en $>$, accessed 10 May 2011.

24 C. Daugbjerg, Reforming the CAP: Policy Networks and Broader Institutional Structures, Journal of Common Market Studies, Vol 37. No. 3, 1999, pp. 407-428.

25 W. Zartman, 'Europe and Africa: Decolonisation or Dependency?’ Foreign Affairs, Vol. 54, No. 2, 1976. pp 325343.

${ }^{26}$ L. Lueschen, op. cit.
} 
realist view of international relations, France wishes to maintain this position to increase its influence and power on the world stage. ${ }^{27}$ Price supports borne by the rest of the EU also ensure that France can sell produce to EU states at vastly more expensive prices than if they bought similar goods on world markets. ${ }^{28}$ As a result, Conybeare states that this meant that mutual defection as opposed to cooperation was a dominant strategy for France in repealing the Blair House Accord. ${ }^{29}$

In strategising how to overturn the Blair House Agreement, France was constrained by a power deficiency relative to the United States.30 As a result, France had to work within the structure of the EU in order to maximise its negotiating power. In delaying use of its veto power in the General Affairs Council and seeking to persuade other EU states to adopt its position on CAP reductions, France maximised strategic benefits from the EU institutional structure, and minimised negative sentiment on its position.

Firstly, an alternate strategy adopted by the French government was to bypass the EU Community and seek to negotiate directly with the US to increase its impact on final Uruguay Round outcome. ${ }^{31}$ This attempt to engage in bilateral negotiations had the advantage of being able to secure a quick resolution. However, the US saw no reason to reopen negotiations on the Accord because it was better off with the original decision, which was less extreme than what France sought to achieve. ${ }^{2}$

One plausible alternative for France was to unilaterally reject the original Blair House Agreement, declare it legally invalid and use its veto in the General Affairs Council to prevent its adoption. This would force the EU to adopt France's position without even needing to engage in consensus building, as the trade policy of the Community is decided as a bloc, allowing France to stall the Uruguay Round indefinitely. 33 Theoretically, developing countries could have given up on their demand for agricultural reform, which would have allowed France to maximize its utility from other Uruguay Round reforms and also indefinitely delaying agricultural reform. This would be a considerable strategic gain; however unilaterally blocking agricultural reform would have been most likely to result in a critical break-down of the Uruguay Round. Developing countries stood to gain most from agricultural reform, 34 and the collapse of the Uruguay Round would have set back achievements on TRIPS, TRIMS and formation of the WTO, which France has been one of the greatest beneficiaries from. 35 Also this would have increased the likelihood that the EU would be excluded from other regional trade deals and suffer exacerbated trade sanctions from the US. ${ }^{6}$ This would allow the US to reap relative gains, resulting in economic and strategic losses for France and the EU.

\footnotetext{
27 J. Ravenhill, op. cit.

28 Europa. 1999. The Overall Impact of the CAP across EU Regions. Regional Policy Sources.

<http://ec.europa.eu/regional_policy/sources/docgener/studies/pdf/chap51_en.pdf >, accessed 10 May 2011.

29 S. Meunier, op. cit.

30 J. Ravenhill, op. cit.

${ }^{31} \mathrm{~S}$. Meunier, op. cit.

32 Ibid.

33 R. Lawrence, et al., op. cit.

34 S. Sharma, 'The World Trade Organization and Implications for Developing Countries,' SAIS Review, Vol. 17,

No.2, 1997, pp. 61-75.

35 S. Meunier, op. cit.

${ }^{36}$ T. Bayard, et al., 'Aggressive Unilateralism and Section 301: Market Opening or Market Closing?', The World Economy, Vol. 15, No. 6, November 1992, pp. 685-706.
} 
In contrast, a more convincing strategy was the push by France to endow the European Commission with offensive trade tools as part of its demand for renegotiating the Blair House Agreement. 37 This was designed so that one single state could not block retaliation against offensive US measures under Section 301, and improve the degree the French could exercise control over the EU in a trade war. 38 The French also sought a defence instrument that would allow the EC to fast track anti-dumping rules. 39 However, this policy was self-defeating, as by reaching an agreement on the Uruguay Round this enabled the formation of the WTO Dispute Settlement Body that has greatly helped France avoid costly trade wars. 40

The final alternative for the French was to offer national co-financing of the CAP, in exchange for a greater degree of EU support to reject or review the Blair House Accord. In order to counter perceived benefits for other EU members in a reduction of the size of the CAP budget, the French could have negotiated to assume a greater role in financing the CAP in exchange for EU support in rejecting the Accord. However the French government has never offered to even talk about national cofinancing, ${ }^{41}$ because much like an individual or corporation, France has an interest in acting as a rent seeker to maintain and strengthen strategic gains. France benefits enormously from the CAP, allowing it to appropriate the economic surplus of other EU States through their contributions to higher prices for French produce because of both subsidies and price supports. ${ }^{2}$ Finally, France was determined to defend these economic benefits and delay reform.

The French policy of coalition and consensus building in the Community was enormously successful in achieving its immediate objective of gaining a review of the Blair House Accord. Furthermore, subsequent trade negotiations had moderate success in reducing the degree of liberalization demanded under the Accord.

Firstly, France was successful in achieving its demand for a review of the Blair House Accord. France persuaded other EU States that the issue was of vital national importance, seen in the credible threat of a veto which was taken seriously by States such as Belgium and Germany. 43 These States were unwilling to allow this situation to escalate and to undermine the EU or to isolate France.44 This enabled France to gain a qualified majority to defend French interests in the General Affairs Council, and gain EU support for a review of the Accord. 45 France used the principal of consensus within the EU to force the US to cave in to its interests or achieve no agreement at all. ${ }^{6}$ Ultimately, stalling the Uruguay Round reduced US bargaining strength at the expense of concessions made to the French Government.

\footnotetext{
37 S. Meunier, op. cit.

${ }^{38}$ Ibid.

39 Ibid.

40 Ibid.

${ }^{41}$ D. Konold, 'Farm Interests as Bargaining Chips: France in the EU-Mercosur Free Trade Negotiations,' Journal of Public Policy, Vol. 30, No.3, pp. 321-343 doi:10.1017/So143814X10000139.

42 Ibid.

43 S. Meunier, op. cit.

44 Ibid.

45 G. Alons, 'European External Trade Policy: the Role of the Franco-German Axis', Radboud University Nijmegen IIEB working paper, 2010. < http://soc.kuleuven.be/iieb/docs/workshops/Paper_Alons.pdf > accessed 15 May 2011.

46 Ibid.
} 
Similarly, France had considerable success in its secondary aim of reducing the degree of liberalization under the Blair House Accord, which actually meant that France was not forced to reduce transfers to farmers. 47 In fact, the use of the 1986-88 base period artificially exaggerated the level of production. $4^{8}$ Paarlberg argues that through the selective use of data points, the conversion of non-tariff barriers to bound tariffs was actually so high it exceeded the original level of protection before the Accord, even after a 36 per cent reduction in protection called for by the Agreement. 49 Also the final Accord reduced the planned retrenchment of export subsidies, so that they did not add any extra impetus to reductions in the MacSharry CAP reforms..$^{\circ}$ In addition, France was able to secure an agreement that there would be no further increases in the set-aside. ${ }^{1} \mathrm{As}$ a result, the French government stated that it had achieved its demands in preserving the livelihood of farmers and recognizing the CAP at the international level..$^{2}$

As well as this, the French were successful in protecting their dominance in agriculture within the EU. The Minimum Access requirement was weakened to between 3 to 5 per cent of Community markets, reducing the degree of competitiveness and maintaining prices at artificially high levels.53 Furthermore, a major amendment to the Accord meant that large cash subsidy programs were not included in the GATT calculations for reducing support to farmers, allowing France to increase compensatory payments. 54 On the other hand, the conversion of non-tariff barriers to tariffs has meant that transfers to agricultural producers are now more visible, as they are from taxpayers rather than producers of food. 55 This may undermine the ability of the French government to reduce pressure from the rest of the EU to curb these welfare losses in the future.

In addition, France was able to protect its agricultural competitiveness in export markets. The French were able to manoeuvre around Blair House restrictions on the production of oilseeds, as the EU supported an increase in the CAP support for the production of biofuel. $.5^{6}$ Moreover, the French were able to extend the Peace Clause from 6 to 9 years, which was designed to prevent further US action against CAP subsidies. 57 This enabled the French to delay further agricultural reform and safeguard their economic rents from CAP reductions. However, Lawrence states that after the Peace Clause expires, the US could use the new WTO Dispute Settlement Body to ensure the CAP becomes a major target under the SCM. $5^{8}$ Ultimately, Paarlberg argues that the final agriculture agreement in the Uruguay Round contributed nothing towards agricultural reform achieved by MacSharry Reforms,

\footnotetext{
47 R. Paarlberg, 'Agricultural Policy Reform and the Uruguay Round: Synergistic Linkage in a Two Level Game?,' International Organization, Vol. 51, No. 3, 1997. pp 413-44.

48 S. Meunier, op. cit.

49 R. Paarlberg op. cit.

5o Ibid.

${ }^{1}$ L. Lueschen, op. cit.

${ }^{2} \mathrm{~S}$. Meunier, op. cit.

53 R. Paarlberg, op. cit.

54 Ibid.

55 W. Coleman et al., 'Against the Odds: Retrenchment in Agriculture in France and the United States,' World Politics, Vol. 49, No. 4, 1997, pp. 453-481.

${ }^{56}$ R. Schnepf, European Union Biofuels Policy and Agriculture: An Overview. US Congressional Research Service Report for Congress. (RS22404; March 16, 2006). Text in: LexisNexis@ Congressional Research Digital Collection, accessed May 5, 2005.

57 S. Meunier, op. cit.

${ }^{8} \mathrm{R}$. Lawrence, et al., op. cit. DSB is a mechanism that the US can resort to which mandates that the EU complies with its decision or compensates the US, or grants authorization for the US to retaliate.
} 
because the US would have defended its agriculture with sanctions anyway. 59 This demonstrates the extent that the French were able to delay and curtail external pressure for reform.

Finally, France achieved strategic institutional benefits through reining in the original autonomy of the Commission negotiating the Blair House Agreement. In reopening negotiations with the Americans, France reinforced the principle of strict intergovernmentalism in the EU, as the Commission required Council approval of important decisions. ${ }^{60}$ Furthermore France reinforced the importance of unanimity as the results of the Uruguay Round had to be approved by consensus. ${ }^{61}$ However, this has been at the expense of Commission legitimacy in negotiating trade agreements in the future. ${ }^{62}$ Ultimately, France has been able to change the institutional rules of the game and made it easier for an economically defensive member state such as itself to capture the EC negotiating position. ${ }^{63}$

In conclusion, in this essay it has been argued that France was able to stymie reform of the Common Agricultural Policy by using the institutional structure and rules of the EU to its advantage in order to block the Blair House Agreement. It was argued that this has resulted in a dilution of the ability of the supranational authority to engage in trade deals, and bolstered French power in the EU through reinforcing the principle of unanimity. Furthermore it has been shown that this will make it easier for France to resist both internal and external pressure to reduce agricultural protection in the future. In conclusion, the rejection of the Blair House Agreement demonstrates the limitations of EU supranational power, and has allowed France to safeguard the permanence of strategic and economic benefits it gains as a result of the Common Agricultural Policy.

\footnotetext{
59 R. Paarlberg, op. cit.

${ }^{60} \mathrm{~S}$. Meunier, op. cit.

61 Ibid.

62 Ibid.

63 Ibid.
} 